\title{
Post-Fire Burn Severity and Vegetation Response Following Eight Large Wildfires Across The Western United States
}

\author{
Leigh B. Lentile ${ }^{1, *}$, Penelope Morgan ${ }^{1}$, Andrew T. Hudak ${ }^{2}$, Michael J. Bobbitt ${ }^{1}$, \\ Sarah A. Lewis ${ }^{2}$, Alistair M.S. Smith' ${ }^{1}$, and Peter R. Robichaud ${ }^{2}$ \\ ${ }^{1}$ University of Idaho, Department of Forest Resources, Moscow, ID 83844-1133 \\ ${ }^{2}$ US Department of Agriculture, Forest Service \\ Rocky Mountain Research Station, Moscow, ID 83843 \\ *Corresponding author: Tel.: (931) 598-3219; e-mail: lblentil@sewanee.edu
}

\begin{abstract}
Vegetation response and burn severity were examined following eight large wildfires that burned in 2003 and 2004: two wildfires in California chaparral, two each in dry and moist mixed-conifer forests in Montana, and two in boreal forests in interior Alaska. Our research objectives were: 1) to characterize one year post-fire vegetation recovery relative to initial fire effects on the soil surface that could potentially serve as indicators of vegetation response (and thus, ultimately longerterm post-fire ecosystem recovery), and 2) to use a remotely-sensed indicator of burn severity to describe landscape patterns in fire effects. We correlated one-year post-fire plant species richness and percent canopy cover to burn severity and to soil surface cover immediately after the fires. For all eight wildfires, plant canopy cover and species richness were low and highly variable one year post-fire. We found a greater number of forbs when compared to other plant life forms, independent of burn severity. Plant cover was dominated by grasses in chaparral systems, by forbs in mixed-conifer forests, and by shrubs in boreal forests, similar to the unburned vegetation. Finescale variability in post-fire effects on soils, the diversity of pre-fire vegetation, and the resilience of plants to fire likely explain the high variation observed in post-fire vegetation responses across sites and burn severities. On most low and moderate burn severity sites, $>30 \%$ of the soil surface was covered with organic material immediately post-fire, and one year later, the canopy cover of understory vegetation averaged $10 \%$ or more, suggesting low risk to post-fire erosion. In California chaparral and the two Montana mixed conifer sites, $5 \%$ or less of the area within the fire perimeter burned with high severity, while in Alaska, 58\% was mapped as high burn severity; we think this is characteristic in Alaska, but uncharacteristic of chaparral fires, especially given the high proportion of non-native species post-fire in our chaparral sites. All fires had a mosaic of different burn severities (as indicated by delta Normalized Burn Ratio, dNBR) with highly variable patch size (mean 1.3 ha to 14.4 ha, range from $<1$ ha to over 100,000 ha).
\end{abstract}

Keywords: dNBR, delta Normalized Burn Ratio, fire effects, remote sensing, species diversity, species richness

Citation: Lentile, L.B, P. Morgan, A.T. Hudak, M.J. Bobbitt, S.A. Lewis, A.M.S. Smith, and P.R. Robichaud. 2007. Post-fire burn severity and vegetation response following eight large wildfires across the western United States. Fire Ecology 3(1): 91-108. 


\section{INTRODUCTION}

Burn severity (Ryan and Noste 1985, Jain et al. 2004, Lentile et al. 2006) classifications are used to infer fire effects on soil and vegetation, potential successional trajectories, and rates of ecosystem recovery, yet this is the first comparison of vegetation response to burn severity across multiple ecosystems. Because large fires are heterogeneous in their effects across the landscape, such events provide ideal opportunities for characterizing initial fire effects and vegetation recovery across the range of burn severities. Ecologists have long recognized the enormous variability in fire effects and vegetation response that results from large wildfires. It is this inherent variation following fire that challenges ecologists to identify unifying trends in burn severity and soil and vegetation response across the post-fire landscape to complement the understanding of fire effects within each ecosystem.

This study was part of a rapid response research project (Lentile et al. 2007) designed to address how fire effects on soil and vegetation differ with burn severity, and to identify measures of immediate post-fire effects that indicate the degree of fire effects on soil and the vegetation response over time. Our research team sampled eight large wildfires, all selected for extended burning over several days to weeks across a diversity of vegetation, soils, and topographic conditions and where satellite images were available for the burned landscape. With the help of fire incident management teams, we identified locations where we could safely establish research plots to sample within a few weeks post-fire (also see Hudak et al. 2007, Lewis et al. 2007), and we sampled the same sites again one year later.

The specific objectives of the research reported here were: 1 ) to characterize one year post-fire vegetation recovery, and 2) to use a remotely-sensed indicator of burn severity to describe landscape patterns in fire effects.
We sought to characterize understory plant vegetation response in areas of different burn severity and to determine which immediate post-fire effects on the soil surface serve as good indicators of one year post-fire soil and vegetation response (and thus, ultimately longer-term post-fire ecosystem recovery). This study is unique for examining vegetation response relative to burn severity using consistent methods across a broad geographic range of vegetation types.

\section{BACKGROUND}

Burn severity influences injury and mortality of plants and the rate of reestablishment of resprouting species (Lyon and Stickney 1976, Ryan and Noste 1985, Morgan and Neuenschwander 1988, DeBano et al. 1998). Whether the removal of some vegetation and altered soil surface conditions is favorable to vegetation depends upon the characteristics of the plant species on the site, their susceptibility to fire, and the means by which they recover after fire (Mutch 1970, Lyon and Stickney 1976, Anderson and Romme 1991, Turner et al. 1998). Alterations to light and nutrient regimes following fires may have major implications for understory plant and seedling recovery in burned stands. We expected greater reductions in understory plant species richness and cover in areas burned more severely. We also expected less rapid recovery of plant cover in severely burned areas.

Plant regeneration may occur from onsite seeds, from off-site seed sources, or from resprouting from deeply buried root and stem structures (Lyon and Stickney 1976). Seed production, and therefore, understory plant community composition and abundance are temporally and spatially variable, and likely influenced by site conditions, the pre-fire plant community, and the post-fire climate (Whelan 1995). Relative to high burn severity, we expected quicker recovery of plant cover in 
low and moderately burned areas due to onsite sources for plant regrowth (sprouts) and establishment (seeds) after fire.

Post-fire forest floor conditions such as the amount of bare soil exposed are important determinants of post-fire vegetation recovery. Litter accumulation may be higher in areas of greatest crown scorch, but lowest where needles were consumed. Scorched needles help to reduce post-fire erosion rates when they blanket the soil surface (Pannkuk and Robichaud 2003). Similarly, the recovery of vegetation is likely to differ by plant functional groups (e.g., moss, grass, forb, or shrub) (Rowe and Scotter 1973). Lower plant species richness was correlated with significant duff consumption in recent wildfires in ponderosa pine forests (Laughlin et al. 2004). Thus, we expected plant species richness and abundance to be lowest where litter and duff were consumed.

Indicators of burn severity, and thus potential ecosystem recovery, could prove useful to post-fire planners tasked with strategically rehabilitating areas likely to recover slowly or in undesirable ways. Remotely-sensed data provide one means by which managers can quickly and consistently evaluate burned areas and identify areas in need of rehabilitation treatment to prevent erosion and weed establishment (Lentile et al. 2006).

\section{METHODS}

\section{Study Sites}

We sampled two wildfires in each of four different geographic areas. Our California (CA) sites were dominated by chaparral vegetation and included the Simi (34 $14^{\circ}$ '56" $\mathrm{N}, 118^{\circ} 49^{\prime}$ '56" $\mathrm{W}$, centroid; elevation 46 to $1118 \mathrm{~m})$ and Old ( $34^{\circ} 11^{\prime} 37^{\prime \prime} \mathrm{N}, 117^{\circ} 15^{\prime} 17^{\prime \prime}$ $\mathrm{W}$, centroid; elevation 396 to $2030 \mathrm{~m}$ ) fires that burned in southern California during the fall of 2003. The Simi fire began on 25 October 2003 and burned 43,800 ha in Ventura and Los
Angeles Counties, while the Old fire began on 28 October 2003 and burned 23,300 ha north of San Bernardino, California. The Simi fire burned in a mix of vegetation types including chaparral, coastal sage scrub, and annual grasslands across a diversity of topographic conditions including rolling hills and very steep, rocky terrain, where annual precipitation is variable, but generally less than $50 \mathrm{~cm}$. The Old fire burned in chaparral mixed with interior woodlands, also on rough terrain.

Chaparral is a shrubby, sclerophyllous vegetation type that is common in middle elevations throughout much of California(Barro and Conard 1991). Chaparral vegetation is highly adapted to stand-replacing fires that were historically common in this ecosystem (Hanes 1977, Keeley 2006b). Common chaparral trees and shrub genera include Adenostoma, Arctostaphylos, Ceanothus, Cercocarpus, Prunus, Quercus, and Rhamnus. Ground cover is relatively sparse when shrubs are dominant, and forbs (e.g., Phacelia, Penstomen, Mimulus species) and grasses are common in these ecosystems following fire. The presence of native forbs and grasses tend to be ephemeral $(<2$ years), although non-native post-fire invaders, including Bromus diandrus, Bromus tectorum, Centaurea solstitialis, Erodium spp., and Trifolium hirtum, may persist longer (Keeley 2006b). Chaparral plant adaptations to fire include post-fire root sprouting, prolific seeding, seed banking, fire-related germination cues, and allelopathy (Hanes 1977, Keeley 2006b). The combined effects of frequent human and natural ignitions, hot dry summers, rainfall limited to mostly the winter, and the high flammability of chaparral vegetation due to volatile compounds and seasonally low fuel moisture (Roberts et al. 2006) make these ecosystems susceptible to intense fires (Barro and Conard 1991, Keeley 2000, Keeley and Fotheringham 2001).

Our western Montana (MT-W) sites were dominated by dry forests and included the 
Black Mountain II (46 $50^{\circ}$ '29' N, $114^{\circ} 10^{\prime}$ 41" W, centroid; elevation 1072 to $1743 \mathrm{~m}$ ) and Cooney Ridge $\left(46^{\circ} 40^{\prime} 10^{\prime \prime} \mathrm{N}, 113^{\circ} 49^{\prime}\right.$ 27 " W, centroid; elevation 1247 to $2167 \mathrm{~m}$ ) fires that burned during the fall of 2003. The Black Mountain II fire began on 8 August 2003 and burned 2,854 ha. The Cooney Ridge fire began on 8 August 2003 and burned 8,589 ha. The Black Mountain II and Cooney Ridge fires burned in mixed-conifer forests of Larix occidentalis, Pinus contorta, Abies lasiocarpa, Pseudotsuga menziesii, and Pinus ponderosa with understories of Xerophyllum tenax, Physocarpus malvaceus, and other species. These lower subalpine forests are generally located on sites with average July temperatures $\sim 17{ }^{\circ} \mathrm{C}$, and mean annual precipitation ranges from $50 \mathrm{~cm}$ to $125 \mathrm{~cm}$ with much falling as snow (Cooper et al. 1991). In general, mixedconifer forest sites like these were historically burned by mixed-severity fires. Here and in the other sites, fire frequency and severity are related to climatic and topographic effects such as wind, temperature, humidity, elevation, and aspect (Fischer and Bradley 1987, Agee 1993), as well as to fire exclusion and past land uses.

Our northwestern Montana (MT-NW) sites were dominated by moist forests and included the Robert (48 $31^{\circ} 14^{\prime \prime} \mathrm{N}, 114^{\circ} 2$ ' 49' W, centroid; elevation 975 to $1961 \mathrm{~m}$ ) and Wedge Canyon fires ( $48^{\circ} 54^{\prime} 22^{\prime \prime} \mathrm{N}, 114^{\circ} 24^{\prime} 14^{\prime \prime}$ $\mathrm{W}$, centroid; elevation 1141 to $2414 \mathrm{~m}$ ). The Robert fire began on 23 July 2003 and burned 23,297 ha, while the Wedge Canyon fire began on 18 July 2003 and burned 21,519 ha. Both fires burned in Flathead County on private and state lands and on federal lands managed by the Flathead National Forest and Glacier National Park. The Robert and Wedge Canyon fires burned in mid-elevation, moist, mixedconifer forests of Tsuga heterophylla, Thuja plicata, Larix occidentalis, Abies lasiocarpa, Pseudotsuga menziesii, Pinus monticola, Pinus contorta, and Picea engelmannii with understories of Vaccinium spp., Xerophyllum tenax, Chimaphila umbellate, and other species. Sites sampled in these forests are relatively moist, receiving $50 \mathrm{~cm}$ to $80 \mathrm{~cm}$ of mean annual precipitation. The relatively deep soils with higher moisture holding capacity make these sites effectively more mesic than the MT-W sites. Fire regimes for these forests are described as moderate frequency (fire return interval of $78 \mathrm{yr}$ (Fischer and Bradley 1987)) and mixed-severity. Mixed-severity regimes may include individual fires that create variable fire effects in a fine-scale mosaic of standreplacing and surface fire (Agee 1998, 2005; Arno et al. 2000).

Our Alaska (AK) sites included the Porcupine and Chicken fires that burned in boreal forests. The Porcupine and Chicken fires eventually merged, along with the Billy Creek and Gardiner Creek fires, to form the

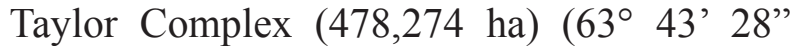
$\mathrm{N}, 142^{\circ} 50^{\prime} 36^{\prime \prime} \mathrm{W}$, centroid; elevation 424 to $1529 \mathrm{~m}$ ) in interior Alaska during the summer and fall of 2004. The Porcupine fire began on 21 June 2004 and burned 115,171 ha. The Chicken fire began on 15 June 2004 and burned 173,651 ha. The Porcupine and Chicken fires burned in interior moist forests of Picea glauca, Picea mariana, Populus tremuloides, Betula papyrifera, Salix spp., and Alnus spp. with deep mats of Hylocomium splendens (feather moss) and other mosses. Historically, wildland fires in the boreal forest tended to burn infrequently, as conditions were commonly too wet to burn. These fires tended to burn slowly, over long periods of time, and to create a patchy mosaic of fire effects that are generally stand-replacing in Picea mariana forests and non-lethal in hardwood forests (Foote 1983). Recent fires have severely burned large expanses of land and, in some cases, consumed future seed sources and exposed permafrost, creating highly variable seed germination and seedling establishment responses (Johnstone and Kasischke 2005, Johnstone and Chapin 2006). 


\section{Vegetation Response Field Data}

Preliminary Burn Area Reflectance Classification (BARC) maps were used as guides to identify potential field sites. Field sites were classified as low, moderate, or high severity if tree crowns were predominantly green, brown, or black, respectively, as called in the field. Sites were selected within areas large enough to include many 30-m Landsat satellite image pixels and be broadly representative of the range of post-fire conditions occurring across the post-fire landscape. Field site centers were placed random distances away from and on compass bearings perpendicular to nearby access roads.

Forty-six sites (Table 1) were established immediately post-fire across the full range of burn severities. Our design was unbalanced, as we purposefully sampled more sites in low and moderate severity because we expected the fire effects and vegetation response to be more heterogeneous for these classes than for high burn severity.

Table 1. Number of sites sampled in each of four different geographic regions by low, moderate and high burn severity classes.

\begin{tabular}{ccccc}
\hline Location & Low & Moderate & High & Total \\
\hline CA & 3 & 6 & 3 & 12 \\
MT-W & 5 & 3 & 2 & 10 \\
MT-NW & 5 & 4 & 3 & 12 \\
AK & 4 & 5 & 3 & 12 \\
Total & 17 & 18 & 11 & 46 \\
\hline
\end{tabular}

Sites consisted of nine plots systematically arranged to span a $130 \mathrm{~m} \mathrm{X} 130 \mathrm{~m}$ area, with plots composed of fifteen $1 \mathrm{~m} \mathrm{X} 1 \mathrm{~m}$ subplots sampling a $9 \mathrm{~m} \mathrm{X} 9 \mathrm{~m}$ area. Sites were oriented according to slope direction. Surface cover fractions of charred organic material (litter, duff, and dead wood), total organic material (charred and uncharred litter duff, and dead wood, but not green vegetation, which was estimated separately), bare mineral soil and ash were ocularly estimated at all 135 subplots as soon as possible following fire. One year postfire, understory species composition and cover were inventoried in four subplots per site. Site locations and the systematic plot and subplot layout are described in more detail by Hudak et al. (2007).

We performed summary and statistical analyses of plot data in SAS version 8.2 (SAS Institute Inc. 2001). We summarized plot data for each class of burn severity at the four geographical locations. We compared values using analysis of variance (PROC GLM, SAS Institute Inc. 2001). Probabilities were computed to determine whether means were significantly different from each other. Variables were tested for significance at the $95 \%$ confidence level $(p<0.05)$.

\section{Landscape Patterns of Burn Severity}

Landsat data were used to calculate the delta Normalized Burn Ratio (dNBR) (Key and Benson 2002) on images taken one year before fire and immediately post-fire. We calculated dNBR because it is the most widely applied burn severity index and is commonly used by practitioners to identify areas in need of postfire mitigation (Lentile et al. 2006). For the purpose of this study, which was primarily concerned with post-fire vegetation response, the use of dNBR to characterize fire effects on vegetation and landscape patterns in burn severity is well supported (Hudak et al. 2007, Lentile et al. 2006.)

We did not employ the Composite Burn Index, a field-based, subjective validation of the post-fire NBR spectral index, due to our emphasis on quantifying multiple biophysical attributes in the field (Hudak et al. 2007). All the images were provided by either Forest Service Remote Sensing Application Center (Montana and California fires) or U.S. Geological Survey Center for Earth Resources Observation and Science (EROS) (Alaska 
fires). Each image was already rectified geometrically and radiometrically, and calibrated to top-of-atmosphere reflectance, following accepted preprocessing procedures (http://landcover.usgs.gov/pdf/image_ preprocessing.pdf). Values were classified according to unburned, low, moderate, and high burn severity thresholds established by Key and Benson (2002). An edge-smoothing utility was applied to smooth class boundaries defined by the dNBR classification and basic patch metrics were generated using ArcGIS (ESRI, Redlands, CA). Size distributions for patches of different burn severity were compared with a nonparametric multi-response permutation test (Mielke and Berry 2001). Multiple comparisons for the multi-response permutation tests were based on Peritz closure (Petrondas and Gabriel 1983) and tested for significance at the $95 \%$ confidence level.

\section{RESULTS}

\section{Vegetation Response}

On all eight wildfires, understory plant canopy cover was low one-year post-fire (Figures 1 and 2). However, vegetation responded quickly post-fire. When we sampled within the first few days or weeks post-fire, many plants were already resprouting and establishing from seed. Most of the species present post-fire were present pre-fire as evidenced by comparing plant communities in burned areas to those in nearby unburned patches.

Total species richness did not differ significantly with burn severity $(\mathrm{p}>0.05)$, partly due to high variability (Figure 1). Most plant species found on burned sites in CA were non-native, whereas few non-native species were observed on plots in other ecosystems, even where burn severity was high. Because some ecosystems are inherently richer in species than others, species richness is much less useful for comparing across ecosystems than for contrasting vegetation response to burn severity within ecosystems. Similarly, we consider comparisons of dNBR values less useful for comparing among ecosystems than within them (Miller and Thode 2007).

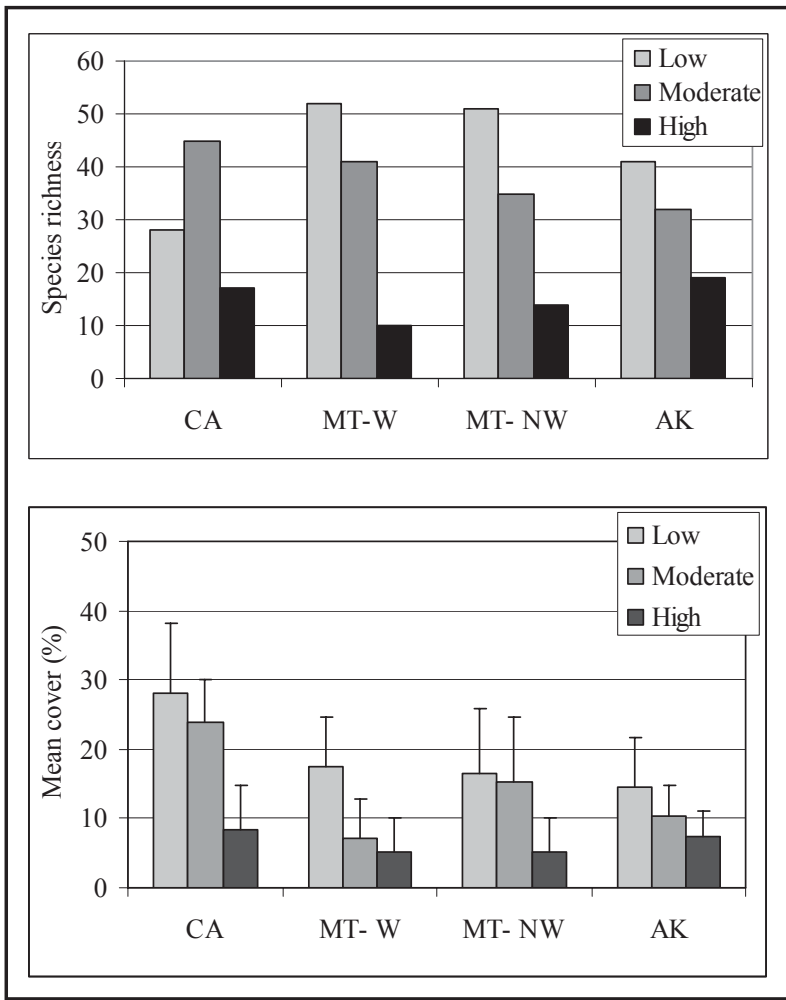

Figure 1. One year post-fire, total plant species richness (top) and mean canopy cover (bottom) compared for areas of low, moderate and high burn severity in two fires in each of four geographic regions. Vertical bars are standard errors (see text for $\mathrm{n}$, which varied with site and burn severity). Standard errors were not calculated for species richness because it represents total number of species across vegetation plots within a site.

Grasses, forbs and shrubs established soon after the fire (Figure 2). Overall, the vegetation post-fire was similar to, though less abundant than, vegetation on adjacent unburned sites, a reflection of the resilience of grasses, forbs, and shrubs to fire. In sites burned with low burn severity, one year post-fire, grass cover was important in the chaparral (CA) and dry forests (MT-W), while forb cover was most prevalent in the moist forests (MT-NW). 
Lichen and moss were abundant in the boreal forests of Alaska (AK). In sites burned with moderate severity, forbs were important in both dry (MT-W) and moist forests (MT-NW), with high percent canopy cover of grasses in CA and shrubs and lichens in AK. Species composition was dominated by forbs independent of burn severity on sites in CA, MT-W and MT-NW, while shrub species were more common on burned sites in AK. Lichen and moss species were also important on AK sites, and, to a lesser degree, on the MT-NW sites. These reflect the relative abundance of plants by growth form in the unburned sites.

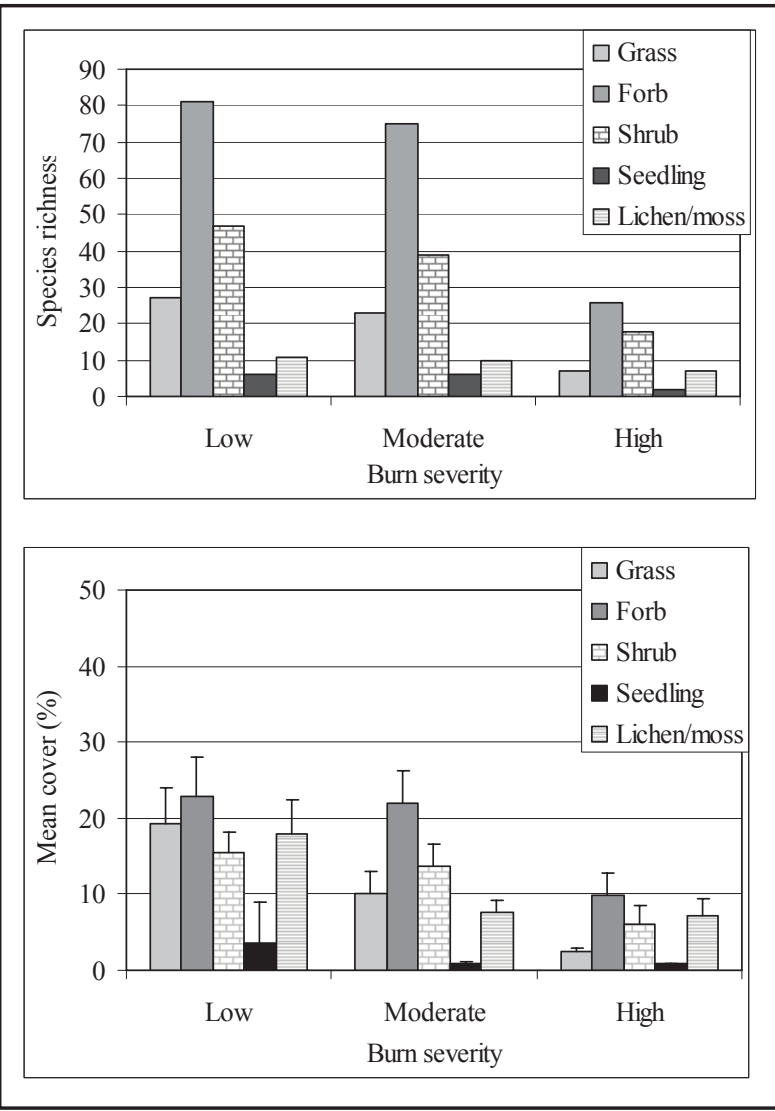

Figure 2. Plant growth form and burn severity for eight wildfires. One-year post-fire total species richness (top) and mean percent canopy cover by plant growth form (bottom). Vertical bars are standard errors (see text for the number of sites sampled in each burn severity class). Standard errors were not calculated for the species richness because these represent total number of species across vegetation plots within a burn severity class.
Post-fire, significantly less litter remained on high burn severity sites than on low or moderate burn severity sites $(\mathrm{p}<0.05$, Figure $3)$. The percent cover of surface organic material differed $(\mathrm{p}<0.05)$ among burn severity classes (Figure 3), and differed more for low and moderate burn severity classes than did depth of litter, except in Alaska, where surface organic cover was highest on moderate burn severity sites. The ocular estimates of surface organic cover did not include green vegetation, which was an important cover fraction on low burn severity sites in Alaska but much less so in the other regions. The deep organic mats in Alaska also caused less soil to be exposed compared to the other regions, across all burn severity classes (Figure 3). The amount of bare soil is another good indicator of burn severity, and varied between burn severity classes across all four ecosystems (Figure 3). The presence of unburned and charred organic matter as well as bare mineral soil likely provides a variety of microsites for plants to survive and recover post-fire (Figure 3).

Several species were common in terms of presence and cover contribution across the range of burn severities and across sites within a geographic region. Such species may provide an indication of common successional trajectories characteristic of a particular severity regime. In CA, grass species commonly observed in all burn severities were non-native Bromus spp. (particularly $B$. diandrus), forb species were the non-native Brassica nigra, the native Calystegia macrostegia cyclostegia, and both native and non-native Cirsium spp., and the native shrub species included Adenostoma fasciculatum, Arctostaphylos spp., and Ceanothus spp. In MT-W, forb species Epilobium angustifolium and Xerophyllum tenax and shrub species Spiraea betulifolia, Vaccinium globulare, and Amelanchier alnifolia were commonly found across burned sites. In MT-NW, forb species, including Epilobium angustifolium, Xerophyllum tenax, and Arnica cordifolia, and 

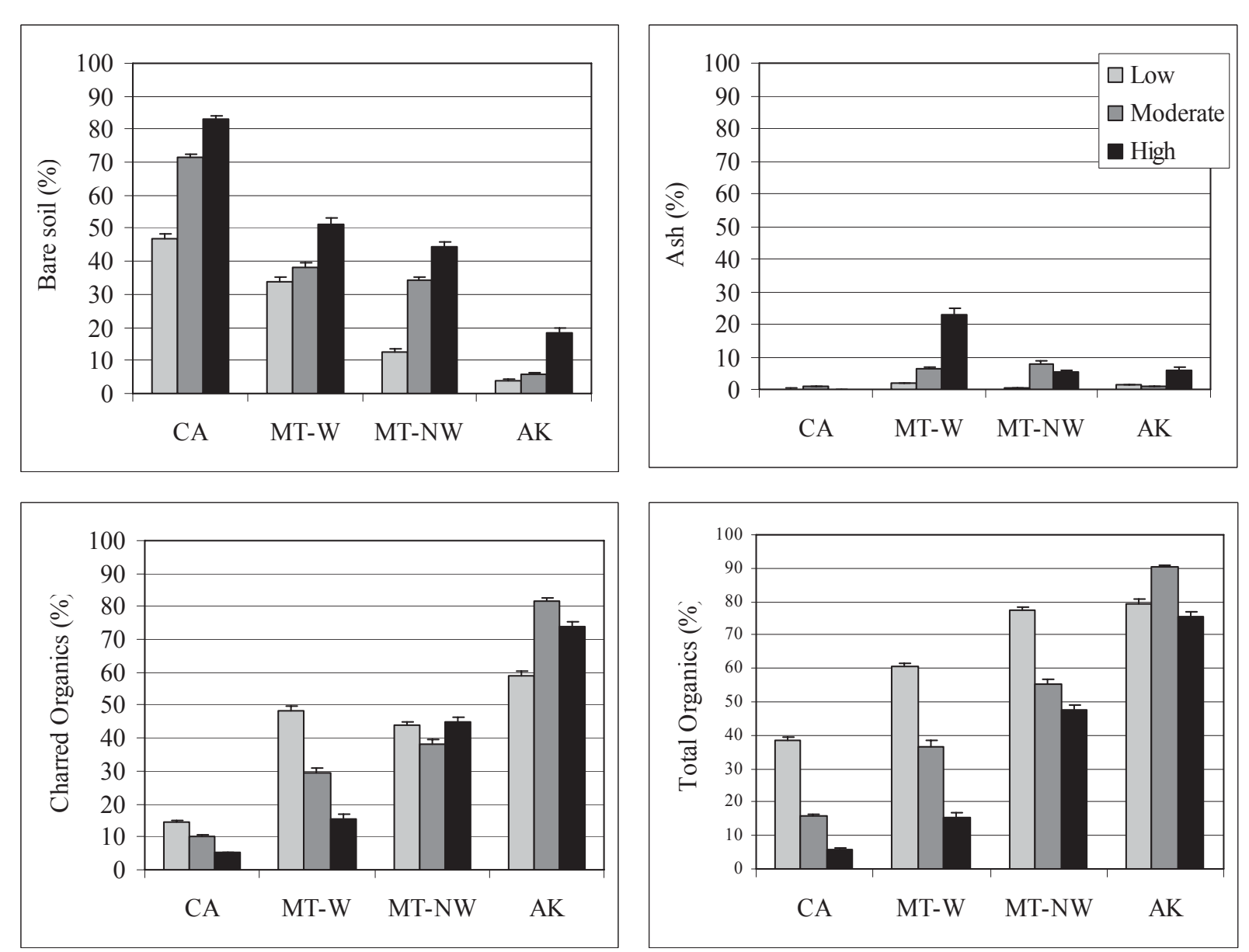

Figure 3. Percent cover of bare soil (top left), ash (top right), charred organic matter (lower left), and total organic material, including both charred and uncharred (lower right). These data were collected soon after and in the same season as fires occurred. Data shown are means and standard errors calculated for all of the 135 subplots on each of the sites sampled within each of two fires in each study region.

shrub species, such as Spiraea betulifolia and Pachistima myrsinites, were common across burn severities. In Alaska, the sedge species, Carex rossii, the forb species Epilobium angustifolium, and the shrub species Vaccinium vitis-idaea and Ledum groenlandicum were found in all burn severities. That there are native species found on plots of all severities is a reflection of both their resilience and multiple life history strategies, for the non-natives it is a reflection of their ability to colonize and exploit altered microsites.

\section{Landscape Patterns of Burn Severity}

The burn severity interpreted from dNBR varied among and within a given fire (Table 2, Figure 4). In the California and Montana fires, less than $5 \%$ of the area within the fire perimeter burned at high burn severity, while in Alaska more than $50 \%$ burned with high severity (Table 2 and Figure 4). In the California and Montana fires, from $14 \%$ to $43 \%$ was unburned (Table 2 ), while $7 \%$ of the Alaska fires was unburned.

The proportion and size of patches burned in different burn severities were dissimilar between regions (Table 2 and Figure 4). 
Table 2. Proportional area burned, patch size (mean and SE), and maximum patch size classified as unburned or as low, moderate, or high burn severity, averaged across two large wildfires in each of four geographic regions. The minimum patch size for all severity levels was $<1$.

\begin{tabular}{|c|c|c|c|c|c|c|c|c|}
\hline \multirow[b]{3}{*}{ Location } & \multicolumn{4}{|c|}{ Unburned } & \multicolumn{4}{|c|}{ Low severity } \\
\hline & \multirow[b]{2}{*}{ Area } & \multicolumn{2}{|c|}{ Patch size } & \multirow{2}{*}{$\begin{array}{l}\text { Maximum } \\
\text { patch size }\end{array}$} & \multirow[b]{2}{*}{ Area } & \multicolumn{2}{|c|}{ Patch size } & \multirow{2}{*}{$\begin{array}{l}\text { Maximum } \\
\text { patch size }\end{array}$} \\
\hline & & Mean & $\mathrm{SE}$ & & & Mean & $\mathrm{SE}$ & \\
\hline & $\%$ & \multicolumn{3}{|c|}{ ………....... ha } & $\%$ & \multicolumn{3}{|c|}{ ………...... ha } \\
\hline $\mathrm{CA}$ & 33 & 3.1 & 4.4 & 10,444 & 28 & 3.7 & 0.9 & 8,270 \\
\hline MT-W & 43 & 21.1 & 11.1 & 4,893 & 9 & 3.3 & 2.5 & 759 \\
\hline MT-NW & 14 & 1.3 & 0.6 & 1,876 & 38 & 4.4 & 1.8 & 3,703 \\
\hline \multirow[t]{3}{*}{$\mathrm{AK}$} & 7 & 2.7 & 0.4 & 3,899 & 5 & 3.9 & 0.2 & 488 \\
\hline & \multicolumn{4}{|c|}{ Moderate severity } & \multicolumn{4}{|c|}{ High severity } \\
\hline & & \multicolumn{2}{|c|}{ Patch size } & \multirow{2}{*}{$\begin{array}{l}\text { Maximum } \\
\text { patch size }\end{array}$} & & \multicolumn{2}{|c|}{ Patch size } & \multirow{2}{*}{$\begin{array}{l}\text { Maximum } \\
\text { patch size }\end{array}$} \\
\hline \multirow[t]{2}{*}{ Location } & Area & Mean & $\mathrm{SE}$ & & Area & Mean & $\mathrm{SE}$ & \\
\hline & $\%$ & \multicolumn{3}{|c|}{ 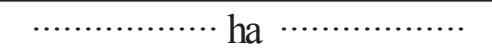 } & $\%$ & \multicolumn{3}{|c|}{ ………....... ha } \\
\hline CA & 35 & 10.2 & 5.1 & 10,410 & 4 & 7.1 & 1.1 & 385 \\
\hline MT-W & 45 & 13.8 & 11.8 & 2,900 & 4 & 10.9 & 4.1 & 253 \\
\hline MT-NW & 43 & 16.6 & 5.8 & 2,637 & 5 & 10.0 & 5.0 & 1,297 \\
\hline $\mathrm{AK}$ & 30 & 7.2 & 0.7 & 6,212 & 58 & 14.4 & 7.3 & 128,510 \\
\hline
\end{tabular}

Patch size was significantly different in low, moderate, and high burn severity in individual fires and across all fires $(p<0.05)$. With the exception of MT-W, unburned patches were the smallest in size. The mean size of low severity patches was consistent across all regions, while the mean size of moderate severity patches in Alaska was anomalously lower than in the other regions. Conversely, the largest high severity patches were much larger in Alaska than in the other three regions $(\mathrm{p}<0.05)$ (Table 2$)$.

\section{DISCUSSION}

\section{Understory Vegetation Response Was Highly Variable}

The high variability in vegetation response following eight large wildfires is not surprising as heterogeneous effects have been documented following other large wildfires (Lyon and Stickney 1974; Turner et al. 1994; Turner and Romme 1994; Whelan 1995; Turner et al. 1997; DeBano et al. 1998; Graham 2003; USDA 2003, 2004). On all sites, the coefficient of variation of understory plant canopy cover was well over 30\% (Figures 1 and 2). Site conditions, pre-fire vegetation composition, and the life-history strategies of individual plant species most likely explain the high variation we observed in post-fire response across sites and burn severities.

Variability in understory plant response was highest for low severity burns, and lowest for high severity burns. Especially on low and moderate burn severity sites, the variety of microsites, including some unburned, some with charred organic cover on the soil, and some with bare soil, likely create conditions for many different plant species to survive, regrow or establish from seed. In general, high severity burn sites have significantly $(\mathrm{p}<0.05)$ more exposed soil and less surface organic matter on the surface than less severely burned sites 

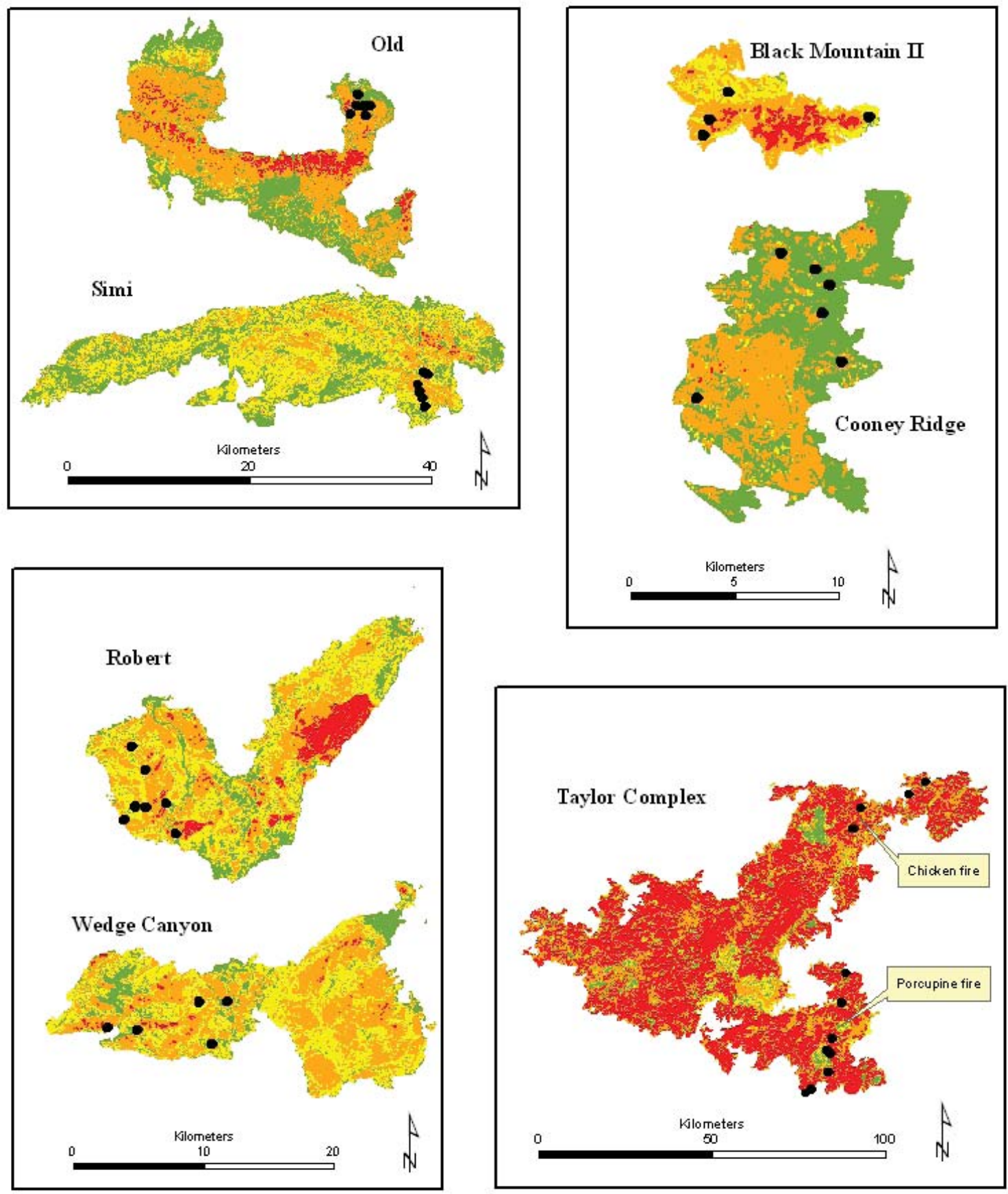

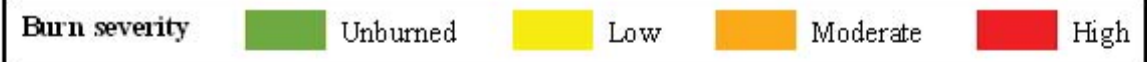

- Site locations

Figure 4. Maps of the burn severity (classified dNBR) for the eight wildfires sampled, two each in four geographic regions. These images show effects of the fires immediately after the fires burned. Note that the extent and therefore the scale varies greatly. 
(Figure 3). We commonly observed unburned, moderately burned, and severely burned microsites within a single $1-\mathrm{m}^{2}$ plot, especially within patches classified as burned at low and moderate severity using dNBR.

In general, sites in CA and MT-W were drier and less productive. Undoubtedly, this contributed to the overall lower amount of total organic material and plant cover measured there in comparison to the moist forests of MT-NW and the boreal forests of AK (Figures 1 and 2).

Post-fire vegetation composition is influenced by the pre-fire composition of resprouting vegetation as well as the composition and condition of the seedbank. Unburned islands of vegetation are also an important source of seed for vegetation that establishes post-fire. In all burn severities, but especially in areas burned with low severity in MT-NW and MT-W, shrubs such as Acer glabrum, Holodiscus discolor, and Amelanchier alnifolia sprouted following topkill from fire. In moderately burned sites in interior AK, scorched Hylocomium splendens and other mosses, Cladina spp., Picea mariana seedlings, Carex spp., and sprouts of Alnus spp., and Betula spp. were commonly observed. The plots in high severity burns in chaparral were dominated by burned shrub skeletons and rocky soil immediately after the fire, and Adenostoma spp. and Ceanothus spp. shrubs had prolifically sprouted within one growing season after the fire, as had Delphinium cardinale and many other forbs that flower following fire. Many of the plant species in the ecosystems we sampled were well-adapted to fire as they exhibited multiple life strategies such as seed-banking and sprouting that ensured successful post-fire regeneration.

As we expected, resprouting was important, especially in areas severely burned. Post-fire responses depend upon the characteristics of the plant species on the site, their susceptibility to fire, and the means by which they recover after fire (DeBano et al. 1998). Many herbaceous and shrub species can regenerate from seed and from rootstock (Lyon and Stickney 1976, Stickney 1986, Anderson and Romme 1991). Lyon and Stickney (1976) found that $86 \%$ of individuals dominant in Pinus contorta stands in the first few years after fire were present before the fire, and 75\% resprouted. Anderson and Romme (1991) found that $67 \%$ of post-fire species survived and that all resprouted after the 1988 Yellowstone fires in Pinus contorta forests. Plant survival and post-fire resprouting has been related to differences in depth distribution of rhizomes in soil (Granstrom and Schimmel 1993, Turner et al. 1997). Surviving vegetation may also produce seeds and facilitate germination or, alternatively, exert a competitive influence.

Many of the species comprising the vegetation response in CA were exotics, even on moderate and low severity field sites. Our field sites on the Simi fire in CA were in Rocky Peaks County Park, a popular mountain biking area, while our Old fire sites are adjacent to the recreational community of Lake Arrowhead. The resulting disturbance surely favored nonnative species. We do not claim that exotic introductions are decoupled from fire in CA; however, Keeley (2006a) showed that wildfires, prescribed fires, and post-fire rehabilitation activities all can contribute to the spread of invasive weeds in CA.

\section{Overstory Fire Effects Influence the Vegetation Below and the Satellite Sensor Above}

Remotely sensed data, in general, more accurately depict post-fire changes in overstory tree canopy than understory or forest floor changes (Hudak et al. 2007), and fire effects on the soil surface appear to vary at finer scales than fire effects on the overstory. Thus, even within areas with relatively uniform fire effects on the overstory (e.g., across a patch we classified as moderate severity) the highly variable post- 
fire soil surface likely contributes to the high variation in vegetation response. Similarly, Turner et al. (1994) found that smaller patches, those less than 1,250 ha in area, were often quite heterogeneous in fire effects on the soil surface. There is also high variability in vegetation present before the burn, which would have affected post-fire vegetation response.

On low burn severity and most moderate burn severity sites we sampled, well over $30 \%$ of the ground surface was covered with organic material immediately after the fire (Figure 3). One-year later, the canopy cover of understory vegetation averaged nearly $10 \%$ and in most areas far more, though the cover was highly variable (Figures 1 and 2). Pannkuk and Robichaud (2003) found that when fallen Pseudotsuga menziesii needles covered $50 \%$ of the soil surface, soil erosion in rills was reduced by $20 \%$ and in interrills by $80 \%$. Robichaud and Brown (2000) correlated lower post-fire erosion rates with pre-fire conditions (e.g., mesic sites where survival of lichens and moss was high, sites where a diversity of grasses, forbs, and shrubs were present before the fire and available to revegetate burned sites) and less steep slopes. The timing and intensity of post-fire rainfall, presence of water-repellent soils, and soil texture also influence the likelihood that significant post-fire soil erosion will occur. It is likely that the vegetation cover will continue to increase quickly, thus providing some soil surface protection as the organic matter remaining post-fire decomposes.

For those ecological effects of fire that depend on the soil, mapping using dNBR is likely most effective at detecting large patches that are severely burned. In areas burned severely, the overstory canopy is largely removed immediately post-fire, and therefore surface reflectance dominates. The fine-scale variation in fire effects on soils and surface organic materials is less detectable on moderate or especially low severity sites where substantial overstory canopy remains after the fire. Burned Area Emergency Response (BAER) teams target areas for post-fire rehabilitation based on burn severity classification maps derived from dNBR values. These maps have been shown to be more influenced by the presence (or lack) of green vegetation than by the amount of surface organic or inorganic cover (Hudak et al. 2007).

\section{Burn Severity Was Heterogeneous Across the Landscape}

Patch size and arrangement can strongly influence the kinds and number of seeds that are dispersed into a burned area (Turner et al. 1994). Mean patch sizes for all eight wildfires were small though highly variable (Table 2), suggesting that seed sources were available for those trees and understory plant species dependent on seed availability from unburned forest. While large patches of high burn severity will have resprouting species and seeds in the soil seedbank post-fire, the vegetation response is likely to be affected by the relatively harsh post-fire environment that is likely in these large patches (Turner et al. 1994, Graham 2003).

In comparison to our observations, patch sizes were large (mean $\sim 3,500$ ha) following the Yellowstone fires, where crown fires burned $31 \%$ of the area (Turner et al. 1997). In both the Rodeo-Chedeski fire that burned $>185,000$ ha of dry mixed conifer forests in Arizona in 2002 and in the Biscuit fire that burned more $>200,000$ ha in both dry and mesic forests in California and Oregon in 2002, mosaics of burn severity resulted (USDA 2003, 2004). Of the national forest lands burned in the RodeoChedeski fire, $~ 54 \%$ burned at moderate or high severity, creating patches greater than several hundred meters across that will presumably take several centuries to re-establish forest cover (USDA 2003). In the Biscuit fire, $\sim 20 \%$ of the area burned lightly, with less than $25 \%$ of the vegetation killed, while another $50 \%$ of the area burned with high severity, with more than $75 \%$ of the vegetation killed (USDA 2004). Patch sizes were also large in the Hayman 
fire in Colorado, where $\sim 50 \%(\sim 28,000$ ha $)$ of the forest was described as burned with high severity, and a single large patch of high burn severity spanned almost 3500 ha (Graham 2003). The proportion and mean patch sizes of high burn severity were much smaller in the fires we sampled, although there were some very large patches in all fires, especially in AK (Table 2 and Figure 4).

In most cases, we found a matrix of surviving vegetation interspersed with patches of high burn severity on the landscape. Similarly, following a large fire $(\sim 34,000$ ha) in Pinus ponderosa forests of the South Dakota Black Hills, large patches were often more heterogeneous in fire effects and less severely burned. Low and moderate severity patches averaged 10 ha and 24 ha, respectively, in size and were within $10 \mathrm{~m}$ of a green edge, while high severity patches were small, averaging 8 ha in size, and $55 \%$ of the area that burned under high severity was within $30 \mathrm{~m}$ of a potential tree seed source in adjacent low or moderate severity patches (Lentile et al. 2005). In AK, even the largest patches of high burn severity included small islands of less severely burned or unburned vegetation. Odion et al. (2004) documented similarly variable mosaics of burn severities for large fires ( $>1500 \mathrm{ha}$ ) burning from 1977 to 2002 on the Klamath National Forest, including $20 \%$ to $82 \%$ low, $5 \%$ to $50 \%$ moderate and $5 \%$ to $45 \%$.

The heterogeneity of fire effects and distance from living vegetation affect vegetation recovery and influence successional trajectories (Pickett and White 1985, Turner et al. 1997). Species richness was lower in larger and more severely burned patches in the cold forests in Yellowstone after the 1988 fires (Turner et al. 1997). Turner et al. (1994) found that smaller patches were often more variable in fire effects and less severely burned, and larger patches were more likely to be less variable in effects and burned with high severity. In Yellowstone, $25 \%$ of the area burned by crown fire was greater than $200 \mathrm{~m}$ from unburned or lightly burned areas (Turner et al. 1994). The juxtaposition of low, moderate, and high burn severity patches will likely mitigate the effects of high burn severity by providing nearby herbaceous and tree seed sources and likely increase rates of plant recovery. Even in the very large patches of high burn severity fires we sampled in boreal forests of Alaska, understory plants were resprouting and seedlings of the serotinous black spruce were established oneyear post-fire.

The scale and homogeneity of fire effects is important ecologically. Often larger fires and large patches within fires are dominated by high burn severity (Turner et al. 1994, Graham 2003). Turner et al. (1994) found that large burned patches ( $\sim 500$ ha to $3700 \mathrm{ha})$ tended to have a greater percentage of crown fire and smaller percentages of light surface burns. Such severely burned areas may be more vulnerable to invasive species and soil erosion and may not return to pre-fire conditions for extended time periods.

\section{Burn Severity and Burn Severity Indicators Vary Between Ecosystems}

It would be useful to have a single measure of burn severity appropriate for different ecosystems, such as dNBR (Key and Benson 2002) or RdNBR (Miller and Thode 2007), both of which are being widely applied. Hudak et al. (2007) and Smith et al. (2007) have suggested percent char because it has many characteristics of an ideal indicator. It is scalable, readily and repeatedly measurable in the field, ecologically meaningful in that it relates to fire effects on both vegetation and soil (Hudak et al. 2007), and is easily interpreted by an ecologist unfamiliar with remote sensing terminology.

Whether absolute thresholds have utility across the widely different ecosystems sampled in this study, or the many other ecosystems to which they might be applied in North America 
and elsewhere, is debatable (Miller and Thode 2007). For burn severity assessments, it is important to first question whether it is really necessary to identify thresholds and classify any indicator, which unavoidably results in a loss of information compared to a continuous variable. We classified dNBR because it was necessary to generate classes and form polygons to allow subsequent calculation of patch metrics. We based our landscape analyses of burn severity classes and patch metrics on one set of dNBR thresholds, for lack of a compelling set of alternative dNBR thresholds. We used dNBR thresholds developed in northwestern Montana (Key and Benson 2002), but this does not mean that this single set of dNBR thresholds is valid for other ecosystems, or even for fires characterized by other satellite images in the same ecosystem (Miller and Thode 2007). The threshold for dNBR between moderate and high burn severity in particular may be illsuited for AK boreal forests, where it appears to result in a higher percent of high burn severity than ecologists find on the ground. Land managers in AK (Karen Murphy, pers. comm.) have suggested that a different threshold for high burn severity may be more ecologically appropriate in these boreal forests, which would effectively decrease the area and mean patch size of high severity fire effects in our AK dataset. The unusually high proportion of the high severity class in Alaska is not evidence that dNBR is an unsuitable metric, but that the threshold between these classes may need to be adjusted (K. A. Murphy, unpublished data).

\section{Are These Observed Vegetation Responses and Burn Severity Patterns Characteristic?}

Although there are too few historical data on fire size and severity to answer this question quantitatively, we can draw upon literature. Large, severely burned patches are probably characteristic in both chaparral (Keeley 2000,
Keeley and Fotheringham 2001) and boreal forests (Kasischke and Barry 2002, Duffy et al. 2007), so our observations that $63 \%$ of the CA sites were burned with low and moderate severity coupled with the many non-native species we found post-fire suggests uncharacteristic fire effects as highlighted by Keeley et al. (2005). In contrast, the large high burn severity patches we found across all sites on the Alaska fires are potentially characteristic. On the other hand, both the number and size of fires are predicted to increase in Alaska due to climate change and this must not be discounted as an explanation (Rupp et al. 2000).

\section{CONCLUSIONS}

Comparing burn severity conditions across large wildfires burning in different vegetation types allows us to describe important general patterns. First, vegetation responds quickly regardless of burn severity and ecosystem. Many plants are well adapted to regrow and establish following fires, even when those fires create large patches burned with high severity. Second, vegetation species richness and percent canopy cover are highly variable among patches burned with low, moderate and high severity. While this is likely the result of the wide variation in pre-fire vegetation and other site conditions, it also reflects the finescale heterogeneity in fire effects within patches that are mapped using dNBR and satellite imagery. Thus, areas mapped as having low and moderate severity encompass microsites that vary from unburned to low, moderate and high severity effects. Third, for this and other reasons, dNBR is a reasonable but imperfect indicator of post-fire fire effects, particularly if it is used primarily to identify high severity fire effects on vegetation and soils, and if the interpretation of what that means is made in the context of each ecosystem. A stand-replacing fire may not be uncharacteristic and outside the evolutionary environment of a particular 
ecosystem, such as boreal forest. Although one year post-fire vegetation response was so highly variable that there were no significant differences among burn severity classes, the immediate post-fire effects on the soil surface did differ among burn severity classes. While it is possible percent surface char (Hudak et al. 2007) could be more useful as an ecological indicator of long-term fire effects, we will not know until we can resample these areas over time. Fourth, extensive areas within even large wildfires that burned intensely have sufficient organic material covering the soil and vegetation that responds quickly to reduce the risks to soil erosion. Further, large wildfires leave a mosaic of unburned vegetation interspersed with areas of low, moderate, and high burn severity. Our data support the approach used by many BAER teams to strategically target post-fire rehabilitation treatments on large, severely burned patches while considering other factors, such as vegetation response, slope, soil texture and resources at risk.

\section{ACKNOWLEDGMENTS}

This research was supported in part by funds provided by the Rocky Mountain Research Station, Forest Service, US Department of Agriculture (Research Joint Venture Agreement 03JV-111222065-279), the Joint Fire Science Program (JFSP 03-2-1-02), and the University of Idaho. Stephanie Jenkins, Bryn Parker, KC Murdock, Carter Stone, Jared Yost, Troy Hensiek, Kate Schneider, Jon Sandquist, Don Shipton, Jim Hedgecock, Scott MacDonald, Curtis Kvamme, and Jacob Young assisted with field data collection and data entry. We appreciate the help of local natural resources managers in each location, as well as the incident management teams. We thank two anonymous reviewers for their constructive comments.

\section{LITERATURE CITED}

Agee, J.K. 1993. Fire ecology of Pacific Northwest forests. Island Press: Washington, DC.

Anderson, J.E. and W.H. Romme. 1991. Initial floristics in lodgepole pine (Pinus contorta) forests following the 1988 Yellowstone fires. International Journal of Wildland Fire 1(2): 119-124.

Arno, S.F., D.J. Parsons, and R.E. Keane. 2000. Mixed-severity fire regimes in the Northern Rocky Mountains: consequences of fire exclusion and options for the future. Pages 225-232 in D.N. Cole, S.F. McCool, W.T. Borrie, and J.O'Laughlin (compilers). Proceedings of the Wilderness Science in a Time of Change Conference, Vol. 5: wilderness ecosystems, threats and management. USDA Forest Service Rocky Mountain Research Station RMRS-P-15-VOL5.

Barro, S.C., and S.G. Conard. 1991. Fire effects on California chaparral systems: an overview. Environment International 17(2-3):135-149.

Cooper, S.V., K.E. Neiman, and D.W. Roberts. 1991. Forest habitat types of northern Idaho: a second approximation. USDA Forest Service General Technical Report INT-236.

DeBano, L.F., D G. Neary, and P.F. Ffolliott. 1998. Fire's effects on ecosystems. John Wiley and Sons: New York, NY.

Duffy, P.A., J. Epting, J.M. Graham, T.S. Rupp, and A.D. McGuire. 2007. Analysis of Alaskan burn severity patterns using remotely sensed data. International Journal of Wildland Fire 16: 227-284. doi: 10.1071/WF06034. 
Fischer, W.C., and A.F. Bradley. 1987. Fire ecology of western Montana forest habitat types. USDA Forest Service General Technical Report INT-223.

Foote, M.J. 1983. Classification, description, and dynamics of plant communities after fire in the taiga of interior Alaska. USDA Forest Service Research Paper PNW-307.

Hanes, T.L. 1977. California chaparral. Pages 417-469 in: M.G. Barbour and J. Major (editors), Terrestrial vegetation of California. John Wiley and Sons, New York.

Hudak, A.T., P. Morgan, M.J. Bobbitt, A.M.S. Smith, S.A. Lewis, L.B. Lentile, P.R. Robichaud, J.T. Clark, and R.A. McKinley. 2007. The relationship of multispectral satellite imagery to immediate fire effects. Fire Ecology 3(1): 64-90.

Jain, T., D. Pilliod, and R. Graham. 2004. Tongue-tied. Wildfire 4: 22-26.

Johnstone, J.F. and E.S. Kasischke. 2005. Stand-level effects of burn severity on post-fire regeneration in a recently-burned black spruce forest. Canadian Journal of Forest Research 5: 2151-2163.

Johnstone, J.F., and F.S. Chapin III. 2006. Effects of soil burn severity on patterns of post-fire tree recruitment in boreal forests. Ecosystems 9: 14-31.

Kasischke, E.S. and W.D, Barry. 2002. Analysis of the patterns of large fires in the boreal forest region of Alaska. International Journal of Wildland Fire 11:131-144. doi:10.1071/WF02023.

Keeley, J.E. 2000. Chaparral. Pages 203-253 in: M.G. Barbour and W.D. Billings (editors), North American terrestrial vegetation. 2nd Edition. Cambridge University Press, New York.

Keeley, J.E., M. Baer-Keeley, and C.J. Fotheringham. 2005. Alien plant dynamics following fire in Mediterranean-climate California shrublands. Ecological Applications 15: 2109-2125.

Keeley, J.E. 2006a. Fire management impacts on invasive plant species in the western United States. Conservation Biology 20:375-384.

Keeley, J.E. 2006b. South coast bioregion. Pages. 350-390 in: N.G. Sugihara, J.W. van Wangtendonk, K.E. Shaffer, J. Fites-Kaufman, and A.E. Thode (editors). Fire in California's Ecosystems. University of California Press, Berkeley.

Keeley, J.E., and C.J. Fotheringham. 2006. Wildfire management on a human dominated landscape: California chaparral wildfires. Pages 69-75 in: G. Wuerthner (editor). Wildfire: a century of failed forest policy. Island Press, Covelo, California.

Key, C.H. and N.C. Benson. 2002. The normalized difference burn ratio (NDBR): a Landsat TM radiometric measure of burn severity. http:/www.nrmsc.usgs.gov/research/ndbr.htm. USGS, Northern Rocky Mountain Science Center, Montana State University, Bozeman, Montana

Lentile L. B., F. W. Smith, and W. D. Shepperd. 2005. Patch structure, fire-scar formation and tree regeneration in a large mixed-severity fire in the South Dakota Black Hills, USA. Canadian Journal of Forest Research 35(12): 2875-2885.

Lentile L., P. Morgan, C. Hardy, A. Hudak, R. Means, P. Robichaud, E. Sutherland, F. Way, S. Lewis, and P. Robichaud. 2007. Lessons learned from rapid response research on wildland fires. Fire Management Today 67(1): 24-31.

Lentile L.B., Z.A. Holden, A.M.S. Smith, M.J. Falkowski, A.T. Hudak, P. Morgan, P.E. Gessler, and N.C. Benson. 2006. Remote sensing techniques to assess active fire and post-fire effects. International Journal of Wildland Fire 15(3): 319-345.

Lewis, S.A., L.B. Lentile, A.T. Hudak, P.R. Robichaud, P. Morgan and M.J. Bobbitt. 2007. Mapping ground cover using hyperspectral remote sensing after the 2003 Simi and Old wildfires in southern California. Fire Ecology 3(1): 109-128. 
Lyon, L.J., and P.F. Stickney. 1976. Early vegetal succession following large northern Rocky Mountain wildfires. Proceedings of the Tall Timbers Fire Ecology Conference 14: 355-375.

Mielke, P.W. Jr., and K.J. Berry. 2001. Permutation methods: a distance function approach. Springer-Verlag, New York.

Miller, J.D., and A.E. Thode. 2007. Quantifying burn severity in a heterogeneous landscape with a relative version of the delta Normalized Burn Ratio (dNBR). Remote Sensing of Environment 109: 66-80.

Morgan, P., and L.F. Neuenschwander. 1988. Shrub response to high and low severity burns. Western Journal of Applied Forestry 3(1):5-9.

Mutch, R.W. 1970. Wildland fires and ecosystems - a hypothesis. Ecology 51(6):1046-1051.

Pannkuk, C.K., and P.R. Robichaud. 2003. Effectiveness of needle cast at reducing erosion after forest fires. Water Resource Research 39 (12):1333-1343 doi:10.1029/2003 WRR002318.

Petrondas, D.A., and K.R. Gabriel. 1983. Multiple Comparisons by Rerandomization Test. Journals of American Statistical Association 78 (384): 949-957.

Roberts, D.A., P.E. Dennison, S. Peterson, S. Sweeney, and J. Rechel. 2006. Evaluation of AVIRIS and MODIS measures of live fuel moisture and fuel condition in a shrubland ecosystem in southern California. Journal of Geophysical Research - Biogeosciences 111:G04S02.

Robichaud, P.R. 2004. Post-fire rehabilitation: are we learning what works? Southwest Hydrology 3(5): 20-21.

Robichaud, P.R., Brown, R.E. 2000. What happened after the smoke cleared: onsite erosion rates after a wildfire in Eastern Oregon. In: Proceedings of the Annual Summer Specialty Conference (Track 2: Wildland Hydrology), 419-426. June 30-July 2, 1999, Bozeman, MT. Herndon, VA: American Water Resources Association.

Roberts, D.A., P.E. Dennison, M.E. Gardner, Y. Hetzel, S.L. Ustin, and C.T. Lee. 2003. Evaluation of the potential of Hyperion for fire danger assessment by comparison to the Airborne Visible/ Infrared Imaging Spectrometer. IEEE Transactions on Geoscience and Remote Sensing 41: 1297-1310.

Roberts, D.A., P.E. Dennison, S. Peterson, S. Sweeney, and J. Rechel. 2006. Evaluation of AVIRIS and MODIS measures of live fuel moisture and fuel condition in a shrubland ecosystem in southern California. Journal of Geophysical Research - Biogeosciences 111: G04S02.

Rowe, J.S., and G.W. Scotter. 1973. Fire in the boreal forest. Quaternary Research 3: 444-464.

Rupp, T.S., A.M. Starfield, and F.S. Chapin III. 2000. A frame-based spatially explicit model of subarctic vegetation response to climatic change: comparison with a point model. Landscape Ecology 15: 383-400.

Ryan, K.C., and N.V. Noste. 1985. Evaluating prescribed fires. Pages 230-238 in: J.E. Lotan, B.M. Kilgore, W.C. Fischer, and R.W. Mutch (technical coordinators). Proceedings- symposium and workshop on wilderness fire. USDA Forest Service General Technical Report INT-182.

Shearer, R.C., and P.F. Stickney. 1991. Natural revegetation of burned and unburned clearcuts in western larch forests of northwest Montana. Pages 66-74 in: S.C. Nodvin and T.A. Waldrop (editors). Fire and the environment: ecological and cultural perspectives. Proceedings of an international symposium. USDA Forest Service General Technical Report SE-69.

Smith, A.M.S., L.B. Lentile, A.T. Hudak, and P. Morgan. 2007. Evaluation of linear spectral unmixing and dNBR for predicting post-fire recovery in a North American ponderosa pine forest. International Journal of Remote Sensing 28(22): 5159-5166. 
Stickney, P.F. 1986. First decade plant succession following the Sundance fire, northern Idaho. USDA Forest Service General Technical Report INT-197.

Turner, M.G., W.L. Baker, C.J. Peterson, and R.K. Peet. 1998. Factors influencing succession: lessons from large, infrequent natural disturbances. Ecosystems 1: 511-523.

Turner, M.G., and W.H. Romme. 1994. Landscape dynamics in crown fire ecosystems. Landscape Ecology 9: 59-77.

Turner, M G., W.W. Hargrove, R.H. Gardner, and W.H. Romme. 1994. Effects of fire on landscape heterogeneity in Yellowstone National Park, Wyoming. Journal of Vegetation Science 5:731742.

Turner, M.G, W.H. Romme, R.H. Gardner, and W.W. Hargrove. 1997. Effects of fire size and pattern on early succession in Yellowstone National Park. Ecological Monographs 67: 411433.

Turner, M.G., W.H. Romme, and R H. Gardner. 1999. Pre-fire heterogeneity, fire severity, and early postfire plant reestablishment in subalpine forests of Yellowstone National Park, Wyoming. International Journal of Wildland Fire 9(1):21-36.

USDA Forest Service. 2003. Rodeo-Chediski Fire Salvage Project Draft Environmental Impact Statement. Apache Sitgreaves and Tonto National Forests. 399 p. http://www.fs.fed.us/r3/asnf/ salvage/publications/RodeoChediski_DEIS.pdf. Accessed April 2, 2007.

USDA Forest Service. 2004. Biscuit Fire Recovery Final Environmental Impact Statement. Rogue River-Siskiyou National Forest and the Medford District of the Bureau of Land Management. http://www.fs.fed.us/r6/rogue-siskiyou/biscuit-fire/feis.shtml. Accessed April 2, 2007.

Wagle, R.F., and J.H. Kitchen. 1972. Influence of fire on soil nutrients in a ponderosa pine type. Ecology 53(1): 118-125.

Whelan, R.J. 1995. The ecology of fire. Cambridge University Press: Cambridge.

White, J.D., K.C. Ryan, and S.W. Running. 1996. Remote sensing of forest fire severity and vegetation recovery. International Journal of Wildland Fire 6: 125-136. 